\title{
ASCITES IN LIVER DISEASE
}

\author{
By Michafl Atkinson, M.D. (Lond.), M.R.C.P. \\ Department of Clinical Research, Unizersity College Hospital Medical School, London
}

Ascites is one of the more common if less spectacular manifestations of liver disease. Indeed in an extensive review of Laennec's cirrhosis, Ratnoff and Patek found it to be the most frequent physical abnormality. Unfortunately our understanding of its pathogenesis is not in keeping with the frequency of its occurrence. In recent years knowledge of various underlying abnormalities has increased without any clear conception of their sequence of events in the pathogenesis of ascites emerging. Of one thing we can be certain however, the presence of ascites implies failure of liver cell function.

The clinical features of ascites in liver disease are too well known to warrant description here. The onset is usually insidious but fluid may accumulate rapidly as for example following thrombosis of the portal vein or sudden deterioration in liver cell function as after bleeding from oesophageal varices.

\section{The Pathogenesis of Ascites}

The derangements leading to ascites formation are both far reaching and complex, involving many systems of the body. Far from being a static collection ascitic fluid is in dynamic equilibrium with the circulation and it has been estimated that $40-80^{\prime \prime}{ }_{0}$ of the volume is exchanged each hour (Prentice et al.). The pouring of fluid into the peritoneal cavity brings into play various compensatory mechanisms which are often extremely difficult to distinguish from the primary derangements involved. In order to evaluate the possible rôle played by the various factors these will be discussed in turn.

Of the primary factors leading to the formation of ascites portal venous hypertension, reduction in serum colloid osmotic pressure, alterations in the permeability of the splanchnic capillary bed and failure of hormone detoxication by the failing liver are of possible significance.

\section{Portal Hypertension}

This alone does not lead to ascites formation. Patients with portal vein thrombosis without underlying liver disease do not develop ascites. Even in the presence of liver damage pronounced portal hypertension may exist for long periods withoutt ascites supervening, as is illustrated by certa patients with cirrhosis who suffer from repeagd gastrointestinal haemorrhage without signs of fle retention appearing.

Work on the experimental animal bears out the्st observations. In the dog constriction of the portil vein will not produce sustained portal hypertension owing to the rapid growth of collateral channess. If the inferior vena cava is also constricted, belgw the liver, portal hypertension will develop. Hotrever ascites can only be precipitated if plasnapheresis is then carried out (Volwiler et al.).

\section{Osmotic Factors}

It is known from clinical observationso ascites only occurs in the presence of liver darmage. The most obvious mechanism would be reduetion in the plasma osmotic pressure, brought about ba reduced plasma albumin level due to liver failure. This would be analogous to plasragpheresis in the experimental animal.

In fluid exchange between capillaries and tiss $\overrightarrow{\overrightarrow{0}}$ Starling put forward the conception of hydrostaic balancing osmotic factors. If ascites is neither creasing nor diminishing, splanchnic capilla pressure minus ascitic fluid hydrostatic pressure balances plasma colloid osmotic pressure misus ascitic colloid osmotic pressure.

Thus, portal hypertension, reflected in an $\frac{0}{3}$ creased splanchnic capillary pressure, and lowe plasma albumin level causing a reduced plasma colloid osmotic pressure, will favour ascites fornation.

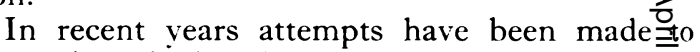
determine whether there is a critical serum osmggic pressure level below which ascites will appear. Bjorneboe et al., studying a group of patients vigh infectious hepatitis progressing to the chronic stage found that serum osmotic pressure ranged frem I 5 I to $229 \mathrm{~mm}$. $\mathrm{H}_{2} \mathrm{O}$ in those with ascites, chpared with values of 237 or more in those with ascites. Others have been unable to verify these findings and Giges and Kunkel in a group of patients with alcoholic, biliary or idiopathic cirirhosis could find no clear relationship between क्षैe 
serum colloid osmotic pressure and the presence or absence of ascites. However in the group with idiopathic cirrhosis, which were presumably mainly post hepatitic in origin and therefore comparable with Bjorneboe's patients, a serum colloid osmotic pressure of $260 \mathrm{~mm}$. $\mathrm{Hg}$. divided those with ascites from those without. The absence of oesophageal varices in Bjorneboe's group indicated that portal hypertension was absent. Hence it seems likely that here the reduction in serum osmotic pressure was of greater relative importance for ascites formation than in patients with established Laennec's cirrhosis in whom portal hypertension would be an additional and variable factor.

\section{Permeability of the Splanchnic Capillary Wall}

In liver disease the protein content of ascitic fluid is higher than that of oedema fluid, which might suggest that the permeability of the splanchnic capillary bed is increased. This is supported by the fact that human serum albumin given intravenously to patients with cirrhosis, rapidly diffuses into the peritoneal cavity so that within 24 hours the serum-ascitic fluid osmotic pressure gradient has returned to its original value (Patek et al.). Schoenberger et al., using radio isotope Iabelled human serum albumin have shown that there is a constant and brisk exchange of albumin between the plasma and ascitic fluid, amounting to 0.4 g. per hour. Yet it seems unlikely that alterations in capillary permeability are important factors in ascites formation as no change in the serumascitic fluid osmotic pressure gradient occurs during spontaneous accumulation or regression of ascites (Patek et al.).

\section{Failure of Detoxication of Hormones}

Antidiuretic hormone (A.D.H.), oestrogens and aldosterone (Chart et al.), have fluid retaining properties and all are thought to be destroyed by the liver. Hence liver damage might perhaps lead to an excess of these hormones in the body and indeed in the case of A.D.H. and aldosterone there is some evidence that an excess is present. However it seems more likely that this is due to an increased rate of production rather than a reduced removal and cirrhotics with ascites do not show an increased sensitivity to injected A.D.H. (Nelson and Welt, White et al.). After oestrogen administration there does appear to be an increased retention of sodium and water in the cirrhotic with ascites compared with normal, and to this extent failure of oestrogen detoxication as a factor in ascites formation has been confirmed (Preedy and Aitken).

\section{Compensatory Mechanisms}

In addition to those already described other abnormalities are present in the cirrhotic accumula- ting ascites which, in the present state of our knowledge, appear to be compensatory factors to combat the loss of fluid into the peritoneum rather than primary mechanisms.

Circulatory factors. The sunken eyes, cold hands and thin pulse of the cirrhotic accumulating ascites suggest that the 'effective' circulating blood volume and the 'effective' extra-cellular fluid are reduced, although the actual values may be high owing to pooling of blood in the splanchnic bed and the presence of acites.

It has been suggested that this leads to a reduction of renal glomerular filtration rate but recent studies indicate that the diurnal rhythm is merely reversed and that the overall 24 hour values are within normal limits. (Jones et al.).

A.D.H. Increased quantities of an antidiuretic substance have been isolated from the urine of cirrhotics with ascites (Ralli et al.). This may be due to an increased production, brought about by the reduced effective circulating blood volume.

\section{Adrenal Salt Retaining Hormone}

Cirrhotics forming ascites avidly retain sodium, nearly all the dietary intake passing to the peritoneal cavity and oedema fluid. The rate of ascites accumulation can be increased or decreased by adding or taking away sodium from the diet. The sweat and saliva contain little sodium and the renal output may be reduced to less than $1 \mathrm{mEq}$ daily (Eisenmenger et al.). This renal retention of sodium is due to an increased tubular reabsorption (Goodyer et al.).

These findings could all be accounted for on a basis of an increased output of adrenal salt retaining hormone. Chart and Shipley reported an excess of a salt retaining factor in the urine of cirrhotics only when ascites was present. More recently this has been identified as aldosterone (Axelrad et al.).

The plasma sodium, potassium and chloride concentrations are low in patients with ascites and cirrhosis (Amatuzio et al.). This hyponatraemia is not accompanied by any symptoms or by uraemia. It occurs in the face of increased body sodium content and appears to represent a resetting of the regulatory mechanisms to maintain a lower level of serum sodium. This hyponatraemia is not simply due to dilution as sodium is retained in the body in excess of water (Talso et al.). Where the excess sodium lies is uncertain. Intracellular sodium has been reported normal (Strub et al.), and it seems most likely that much of it is stored in bone. The cause of this hyponatraemia is unknown. Analogous states occur in congestive cardiac failure and other chronic diseases and may represent some fundamental change in cell metabolism. 


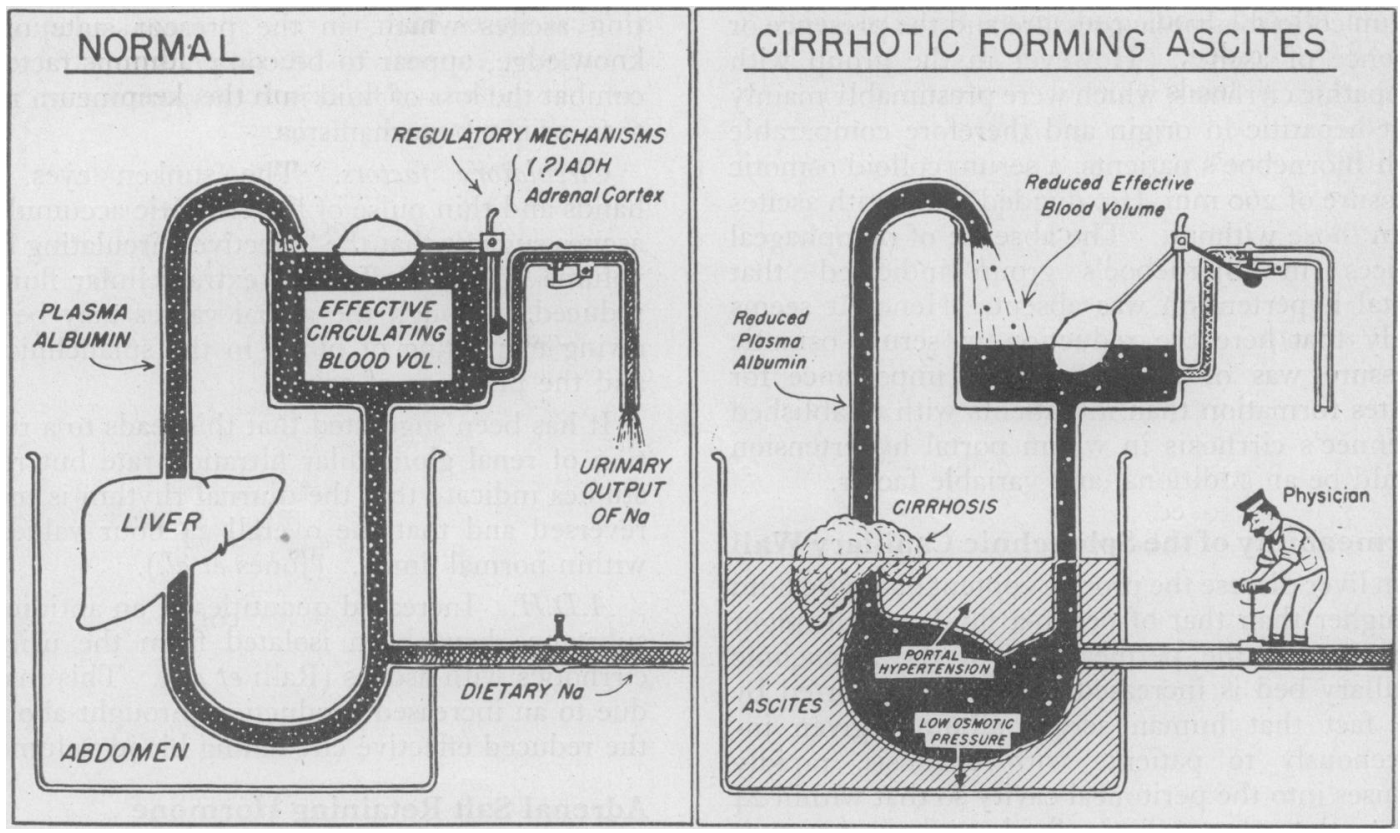

FIG. I.

\section{The Site of Formation of Ascites}

The observation that ligation of the inferior vena cava above the liver in the dog causes a great outpouring of hepatic lymph has led some to believe that ascitic fluid may originate in the liver rather than from the peritoneal surface (Volwiler et al., Hyatt et al.). Perhaps Hippocates had this in mind in his aphorism, 'When the liver is full of fluid and this overflows into the peritoneal cavity, so that the belly becomes full of water, death follows.' The rather high protein content of the ascitic fluid and the absence of oedema of the intestinal wall could be accounted for on this basis. Such factors as portal hypertension and plasma osmotic pressure might be expected to exert their effects from within the liver on hepatic lymph flow, just as exactly as in the splanchnic capillary bed.

This conception of ascites formation offers a new and interesting approach which as yet has proved difficult to substantiate or refute.

In summary portal hypertension and reduced plasma albumin appear to be the important primary factors in initiating ascites formation. The loss of fluid into the peritoneum leads to a reduction in effective circulating blood volume and effective extracellular fluid volume. These may lead to an increased output of A.D.H. and aldosterone which appear to be compensatory mechanisms (see Fig. I).

\section{The Treatment of Ascites}

Measures aimed at reducing portal hypertension or increasing plasma albumin concentration are o⿺辶⿸广巳 little practical value in the management of the ascites of liver disease. These patients are in nogfite state for a portal caval anastomosis and human poor serum albumin has proved disappointing aqiं rapidly passes into the peritoneal cavity and pro울 duces little if any decrease in the rate of ascites formation (Patek et al., Faloon et al.). Treatmeno then aims at controlling ascites formation by in direct measures rather than by removing the primary causative factors. Dietary sodium restric을 tion forms the basis of therapy, supplemented if necessary by diuretics to increase urinary sodiun output.

A reduction of sodium intake to $22 \mathrm{mEq}(0.5 \mathrm{~g}$. daily is usually effective in controlling ascites. formation (Atkinson et al.). In refractory cases may be necessary to reduce the intake still further to ro $\mathrm{mEq}$ daily, but this is done at the expense o\$ variety and palatability in the diet and is infre quently required.

Details of low sodium diets are readily available (Sherlock) and will not be described in detail here. With the aid of the dietitian and a resourceful cools it is possible to provide an interesting and palatableu diet. This entails the avoidance of salt at table and in cooking and the consumption of salt free breafs and butter. The intake of milk and milk products should be restricted owing to the high sodium con tent ( $6 \mathrm{mEq} /$ half pint) but a variety of sodium free milk substitutes are now available. Foods high in sodium such as cakes, etc., containing baking soda 
certain canned foods and many breakfast cereals should be avoided.

In general foods rich in protein have a high sodium content. Patients with cirrhosis and ascites should maintain a protein intake of the order of $100-120 \mathrm{~g}$. daily as undernutrition is frequently present. This can be achieved by the use of various high protein low sodium supplements, e.g., Casilan (Glaxo).

Treatment is best started in the hospital, with bed rest and alcohol withdrawal, as Klatskin and Yesner have shown that these measures alone may result in a regression of ascites. With dietary sodium restriction the rate of ascites formation can usually be controlled. If this does not occur within two or three weeks it may be necessary to use mercurial diuretics and ammonium chloride to increase the output of sodium in the urine. During this time careful check should be kept on body weight, fluid intake and output and the serum electrolyte levels measured at weekly intervals.

Ion exchange resins have proved to be of little value in the control of ascites, owing to their unpleasantness to take and the complications of hypokalaemia and acidosis following prolonged use.

Paracentesis abdominis is to be avoided where ever possible owing to the risks of precipitating shock and low sodium syndromes or hepatic cama, and the fact that it leads to considerable protein loss from the body. Nowadays it is seldom required but may still be called for to relieve acute local discomfort due to abdominal distention. It should be performed slowly and it is as well to withhold mercurial diuretic for some days afterwards to avoid the complication of shock and sodium depletion.

Many surgical procedures, ranging from hepatic artery ligation to adrenalectomy, have been suggested for the control of ascites. All carry a high risk because of the presence of liver cell failure and have little place in present day treatment.

\section{The Complications of Treatment}

It will be apparent that the regime outlined is not completely free of risk to the patient, yet with adequate care, the dangers are slight.

Sodium depletion. It might be expected after a period on a low sodium diet plus frequent injections of mercurial diuretics that sodium depletion, with its clinical picture of hyponatraemia, hypotension and uraemia, would result. As mentioned previously however, cirrhotics have increased stores of sodium in the body which act as a reservoir and a buffer and such symptoms are uncommon. Paracentesis is particularly likely to precipitate sodium depletion (Nelson et al.), especially in the presence of advanced cirrhosis, where the sodium stores may not be mobilized adequately. Treatment consists of the slow administration of isotonic sodium chloride solution keeping a careful watch for pulmonary oedema.

It is important to distinguish the asymptomatic hyponatraemia of cirrhosis from the picture of sodium depletion. This is not accompanied by signs of shock or uraemia and requires no treatment.

Potassium depletion. This may result from the continued use of mercurial diuretics and ammonium chloride (Hilton). Hence a regular check of serum electrolyte levels should be kept. It should be combated by oral potassium salts e.g. potassium chloride $4-6 \mathrm{~g}$. ( $50-75 \mathrm{mEq}$ ) daily.

Hepatic coma. Phillips et al. have emphasized that ammonium compounds and a high protein diet may precipitate hepatic coma in patients with cirrhosis. This had led many to abandon these measures in the management of the ascites of cirrhosis; a patent example of the misapplication. of the results of clinical research. Most patients with cirrhosis and ascites will tolerate a $120 \mathrm{~g}$. protein diet and $3 \mathrm{~g}$. of ammonium chloride daily without ill effect. With careful observation early signs of neurological disorder can be detected and the offending agent discontinued without permanent harm resulting. To abandon these measures in the management of the ascites of liver disease is to discard valuable, and at present irreplaceable, adjuncts to treatment.

\section{The Ultimate Prognosis}

Eventually the patient leaves hospital on his low sodium diet supplemented perhaps by diuretics; what then is the outlook for the future? This will depend largely on the patient himself, whether he is willing and able to continue the regime and to avoid alcohol. Home circumstances may preclude a strict low sodium diet as so many of these patients live alone and dine out. For these patients some form of long term institutional care would be welcome.

If the patient continues carefully on the regimen what then is the ultimate outlook ? He may still succumb to bleeding from oesophageal varices or to liver cell failure. Provided that these do not supervene, there is evidence that his general nutrition and sodium tolerance will slowly improve (Davidson). Should surgery for portal hypertension now be required he is in suitable condition to withstand operation.

\section{BIBLIOGRAPHY}

AMATUZIO, D. S., STUTZMAN, F., SHRIFTER, N., and NESBIT'T, S. (I952), f. Lab. clin. Med., 39, 26.

ATKINSON, M., PATON, A., and SHERLOCK, S. (1954), Lancet, $\mathbf{i}, 128$.

Continued on page 494 


\section{Acknowledgments}

We are grateful to Dr. Sheila Sherlock and Dr. Charles S. Davidson for allowing us to study patients under their care. We wish to thank the Medical Research Council for a personal grant to one of us (E.A.D.).

\section{BIBLIOGRAPHY}

ADAMS, R. D., and FOLEy, J. M. (1953), Res. Publ. Assn. Res. Nerv. Ment. Dis., 32, 198.

ANON., 'De Morbis Internis,' 27.

ATKINSON, M., BARNETT, E., SHERLOCK, S., and STEINER, R. E. (1955), Quart. F. Med., n.s. 24, 77 .

BAUMANN, E. D. (193I), fanus 35,153 and 185 .

BENHAMOU, J. P., HARTMANN, L., and FAUVERT, R. (I955), Presse medicale, 63, $145 \mathrm{I}$.

FINDLAY, G. M., and MARTIN, N. H. (1943), Lancet, i, 678.

FORD, J. C. (1943), Ibid., I, 675.

GALEN (A.D. 131-200), quoted by Baumann, E. D.

HIPPOCRATES (460-370 B.C). 'Epidemiorum,' 3: 'Hippocrates with an English Translation,' W. H. S. Jones, I, 219, Heinemann, London.

HIPPOCRATES (460-370 B.c). 'The Sacred Disease,' 18 : 'Hippocrates with an English Translation,' W. H. S. Jones, 2 177, Heinemann, London.
KIRK, E. (1936), Acta. med. Scand., 77, suppl. p. I.

LICHTMAN, S. S. (1953), 'Diseases of Liver, Gall Bladder and0̄ Bile Ducts,' r, 484, 3rd Ed., Klimpton, London.

LEIBOWITZ, S., and GORMAN, W. F. (1952), New Engl. $\not{y} . Z$ Med. 246, 932.

MAYER-GROSS, W., SLATER, E., and ROTH, M. (1954) @ 'Clinical Psychiatry,' p. 299. Cassell \& Co. Ltd., London.

MCDERMOTT, W. V., Jr., and ADAMS, R. D. (1954), f. clin Invest., 33, I.

PHILLIPS, G. B., SCHWARTZ, R., GABUZDA, G. J., Jr. DAVIDSON, C. S. (1952), New Engl. F. Med., 247, 239.

QUASTEL, J. H. (1932), Lancet, ii, 1417.

SOLOMON, P., and ARING, C. D. (1934), Amer. F. med. Sci., 188,805 .

SPENCE, J. C., and OGILVIE, A. G. (1927), Arch. Dis. Childh. $\stackrel{\mathbb{Q}}{\varrho}$ 2, $4 \mathrm{I}$.

SHERLOCK, S., SUMMERSKILL, W. H. J:, WHITE, L. P., ڤ) and PHEAR, E. A. (1954), Lancet, ii, 453.

SHERLOCK, S., and WALSHE, V. (1946), Lancet, ii, 482.

SUMMERSKILL, W.H. J., DAVIDSON, E.A., SHERLOCK,'S. and STEINER, R. E. (I956), Quart. $\mathscr{F}$. Med. n.s. 25, 245.

VAN CAULAERT, C., DEVILLER, C., and HALFF, (1932), C. R. Soc. Biol., Paris, III, 735.

VICTOR, M., and ADAMS, R. D. (1953), A. Res. Nerv. and Ment Dis. Proc., 32, 526.

VON JAUREGG, W. (1806); Wien Klin. Wochenschr., 9, 165. WOOLER, G. (1955), Personal communication.

ZILLIG, G. (1947), Nervenarzt, 18, 297.

\section{RUTHIN CASTLE, NORTH WALES}

A Clinic for the diagnosis and treatment of Internal Diseases (except Mental or Infectious Diseases). The Clinic is provided with a staff of doctors, technicians and nurses.

The surroundings are beautiful. The climate is mild. There is central heating throughout. The annual rainfall is 30.5 inches, that is, less than the average for England.

The Fees are inclusive and vary according to the room occupied.

For particulars apply to THE SECRETARY, Ruthin Castle, North Wales.

Telegrams: Cascle, Ruthin.

Telophone: Ruchin 66

Bibliography continued from page 485-Michael Atkinson, M.D. (Lond.), M.R.C.P.

AXELRAD B. J, CATES, J, E, JOHNSON, B, B, and LUETSCHER, J. A. (1955), Brit. med. F., i, I96.

BJORNEBOE, M., BRUN, C., and RAASCHOU, F. (1949), Arch. Int. Med., 83, 539 .

CHART, J. J., SHIPLEY, E. G. (1953), f. clin. Invest., 32, 560.

CHART, J. J., GORDON, E. S., HELMER, P., and LESHER, M. (1956), 7. clin. Invest., 35, 254.

DAVIDSON, C. S. (1955), F. Amer. med. Ass., 159, 1257.

EISENMENGER, W. J., BLONDHEIM, S., BONGIOVANNI, A. M., and KUNKEL, H. G. (1950), $\mathcal{f}$. clin. Invest., 29, 1491 .

FALOON, W. W., ECKHARDT, R. D., MURPHY, T. L. COOPER, A. M., and DAVIDSON, C. S. (1949), $\mathcal{F}$. clin. Invest., 28,583 .

GIGES, B., and KUNKEL, H. G. (1954), F. clin. Invest., 33, 257. GOODYER, A. V. N., RELMAN, A. S., LAWRASON, F. D., and EPSTEIN, F. H. (1950), ' F. clin. Invest., 29, 973.

HILTON, J. G. (1952), Am. F. Med., 12, 31 I.

HYATT, R. E., LAWRENCE, G. H., and SMITH, J. R. (1955), F. Lab. Clin. Med., 45, 274.

JONES, R. A., MCDONALD, G. O., and LAST, J. H. (1952), F. clin. Invest., $3 \mathrm{I}, 326$.

KLATSKIN, G., and YESNER, R. (1949), F. clin. Invest., 28, 723.

NELSON, W. P., and WELT, L. G. (1952), F. clin. Invest., 31, 392.

NELSON, W. P., ROSENBAUM, J. D., and STRAUSS, M. B. (1951), $\Im$. clin. Invest., 30, 738 .
PATEK, A. J., MANKIN, H., COLCHER, H., LOWELL, A. and EARLE, J. R. (1948), ' 7 . clin. Invest., 27, 135.

PHILLIPS, G. B. SCHWARTZ, R., GABUZDA, G. J., and DAVIDSON, C. S. (1952), New Engl. F. Med., 247, 239 .

PREEDY, J. R. K., and AITKEN, E. H. (1956), Ұ. clin. Invest., 35, 430.

PRENTICE, T. C., SIRI, W., and JOINER, E. E. (1952), $A m .0$ F. Med., 13, 668 .

RALLI, E. P., ROBSON, J. S., CLARKE, D., and HOAGLAND, C. L. (1945), . clin. Invest., 24, 316.

RATNOFF, O. D., and PATEK, A. J. (1942), Medicine, 21, 207. SCHOENBERGER, J. A., KROLL, G., SAKAMOTO, A., andN KARK, R. M. (1952), $¥$. Lab. clin. Med., 40, 94I.

SHERLOCK, S. (1955), 'Diseases of the Liver and Biliary System, $N$ Blackwell Scientific Publications, Oxford.

STARLING, E. H. (1896), f. Physiol., 19, 312.

STRUB, I. H., TALSO, P. J., and KIRSNER, J. B. (I955) Gastroenterology, 28, 163

TALSO, P. J., SPAFFORD, N., FERENZI, G., and JACKSON, H. O. (1956), Metabolism, 5, 58.

VOLWILER, W., GRINDLAY, J. H., and BOLLMAN, J. L. (1950), Gastroenterology, 14, 40.

WHITE, A. G., RUBIN, G., and LEITER, L. (195I), f. clin. $\frac{T}{\top}$ Invest., 31, 392. 